\title{
Update on schizophrenia and bipolar disorder: focus on cariprazine
}

\author{
This article was published in the following Dove Press journal: \\ Neuropsychiatric Disease and Treatment \\ 25 July 2016 \\ Number of times this article has been viewed
}

\author{
Rona Jeannie Roberts' \\ Lillian Jan Findlay ${ }^{2}$ \\ Peggy L El-Mallakh² \\ Rif S El-Mallakh' \\ 'Mood Disorders Research Program, \\ Department of Psychiatry and \\ Behavioral Sciences, University \\ of Louisville School of Medicine, \\ Louisville, ${ }^{2}$ School of Nursing, \\ University of Kentucky, Lexington, \\ KY, USA
}

\begin{abstract}
Schizophrenia and bipolar disorder are severe psychiatric disorders that are frequently associated with persistent symptoms and significant dysfunction. While there are a multitude of psychopharmacologic agents are available for treatment of these illnesses, suboptimal response and significant adverse consequences limit their utility. Cariprazine is a new, novel antipsychotic medication with dopamine D2 and D3 partial agonist effects. Its safety and efficacy have been investigated in acute psychosis of schizophrenia, bipolar mania, bipolar depression, and unipolar depression. Efficacy has been demonstrated in schizophrenia and mania. It is unclear if cariprazine is effective in depression associated with unipolar or bipolar illness. Adverse consequences include extrapyramidal symptoms including akathisia, and various gastrointestinal symptoms. The US Food and Drug Administration (FDA) has recently approved cariprazine. This review will provide clinicians with basic information regarding the research program of cariprazine.
\end{abstract}

Keywords: cariprazine, dopamine D3 receptor, dopamine D2 receptor, bipolar disorder, mania, bipolar depression, schizophrenia

\section{Introduction}

Schizophrenia is a severe and persistent mental illness and treatment is woefully inadequate for the majority of afflicted individuals. Nearly all available antipsychotic agents are dopamine D2, D3, and/or D4 receptor antagonists. ${ }^{1}$ More recently, partial agonistic action at D2 and D3 receptors has suggested that this may be a promising approach. ${ }^{2}$ Three partial agonist compounds have now been approved for acute psychosis associated with schizophrenia by the US Food and Drug Administration (FDA): aripiprazole, brexpiprazole, and cariprazine. The newest of these, cariprazine, has unique properties that may affect its clinical profile.

Similarly, bipolar illness is a severe, recurring illness. While psychosis is a common symptom in manic and depressed individuals with bipolar I disorder, antipsychotic agents have demonstrated efficacy independent of the presence of psychosis. ${ }^{3}$ Furthermore, antipsychotics with antidepressant potential have helped fulfill an unmet need for bipolar patients. ${ }^{4,5}$ Cariprazine has been studied in this population as well.

Cariprazine is a piperazine derivative that was developed by Geoden-Richter in Hungary. Initially, scientists identified trans- $N$-[4-[2-[4-(2,3-dichlorophenyl)piperazin1-yl] ethyl]cyclohexyl]- $N$, $N$ '-dimethylurea hydrochloride or " $2 \mathrm{~m}$ " as an impurity in biosynthetic experiments. ${ }^{6}$ However, subsequent analysis revealed that this impurity was more promising than the original research target. ${ }^{6}$ The drug was subsequently named cariprazine (RGH-188) and investigated clinically for both schizophrenia and depression in unipolar and bipolar illness. 


\section{Pharmacodynamics and pharmacokinetics}

Cariprazine is a partial agonist at the dopamine D2 and D3, and the serotonin $5 \mathrm{HT}_{1 \mathrm{~A}}$ receptors. ${ }^{7}$ It has high affinity to these receptors $\left(\mathrm{Ki}=0.5,0.085\right.$, and $3.0 \mathrm{nM}$, respectively $\left.{ }^{8}\right)$ as well as serotonin $5 \mathrm{HT}_{2 \mathrm{~B}}$ and $5 \mathrm{HT}_{2 \mathrm{~A}}$ receptors. ${ }^{8}$ At doses approaching 2-3 mg per day, cariprazine receptor occupancy easily exceeds $85 \%$ for D2 and D3 receptors in monkeys. ${ }^{9}$ In humans with schizophrenia, $1.5 \mathrm{mg}$ daily will achieve $69 \%-75 \%$ receptor occupancy. ${ }^{10}$ In nonpsychotic controls, doses of $1 \mathrm{mg}$ daily achieve over $65 \%$ receptor occupancy. ${ }^{11}$ Serotonin $5 \mathrm{HT}_{1 \mathrm{~A}}$ receptor occupancy never exceeds $30 \%$ despite a high affinity. ${ }^{9}$ Cariprazine is safe and effective in dose ranges 3-12 mg daily.

The half-life of cariprazine is $\sim 2-6$ days. ${ }^{12,13} \mathrm{C}_{\max }$ for cariprazine is achieved in 3-4 hours after an oral dose, but because of a half-life of 2-6 days, achieves steady state in over a week. ${ }^{12,13}$ Furthermore, it has two active metabolites, desmethyl-cariprazine and didesmethyl-cariprazine, ${ }^{14}$ which prolong time to functional steady state to over 1 month. Metabolism occurs through CYP450 3A4 and, to a lesser extent, CYP450 2D6. ${ }^{15}$

Partial dopamine agonist antipsychotics allow clinicians to obtain clinical efficacy while minimizing dopamine-related adverse events (AEs). Dopamine-mediated AEs occur when receptor occupancy exceeds $80 \%{ }^{16}$ in both animals ${ }^{17}$ and humans. ${ }^{18,19}$ This is so close to the $65 \%$ D2 occupancy which is required to achieve the antipsychotic effect ${ }^{20,21}$ that it is difficult to titrate the dose appropriately, and clinicians generally use antipsychotics at $90 \%$ occupancy. ${ }^{22}$

Cariprazine, and other high-affinity partial agonists, solve this problem. When cariprazine is administered at a dose that occupies $95 \%$ of the $\mathrm{D} 2$ receptors, the partial activation produces an apparent lower level of blockade. The level of partial activation needs to mimic the natural tonic dopamine signal in the brain, $\sim 20 \%-25 \%$ of the maximal dopamine signal. ${ }^{23}$ Thus, partial agonists must stimulate the $\mathrm{D} 2$ receptor at a level similar to this. Cariprazine may reduce the risk of dopamine-related AEs even further due to its partial agonistic effect on $5 \mathrm{HT}_{1 \mathrm{~A}}$, which may reduce extrapyramidal symptoms and improve mood and cognition. ${ }^{24-26}$ The reduction of D2-mediated AEs is essentially quantified in the serum prolactin data. In long-term safety studies in patients with schizophrenia, mean prolactin levels drop by $18.3 \mathrm{ng} / \mathrm{mL}$ at 48 weeks versus baseline (dose range from 1.9 to $9 \mathrm{mg} /$ day). While some of this reduction may be related to some of the patients coming off a prolactin-increasing antipsychotic, the reduction is consistent with the activation of $\mathrm{D} 2$ receptors at/near the natural tonic level of dopamine by the partial agonist effect of the drug.

Partial agonism may also play an important role that is specific to the pathophysiology of schizophrenia. Recent positron emission tomography studies suggest that patients with early or chronic schizophrenia have an increase in dopamine synthesis and dopamine release. ${ }^{27-30}$ However, the synaptic density is unchanged versus controls, ${ }^{31}$ suggesting that the amount of dopamine per synapse in patients with schizophrenia is increased. Indeed, there is evidence that in subjects with schizophrenia and at-risk individuals, the dopamine system is hyperresponsive..$^{30,32}$ A high-affinity partial agonist will fully prevent endogenous dopamine from interacting with postsynaptic receptors while creating a partial dopamine signal that normalizes functional dopamine signal.

Cariprazine is generally described as a D3-preferring agent. The D3 receptor has the highest density of expression in the nucleus accumbens and olfactory tubercle. ${ }^{27-29}$ Overexpression of $\mathrm{D} 3$ reduces motivation in mice, ${ }^{30}$ and blockade of D3 improves cognition and reduces hyperactivity in rats. ${ }^{31}$ While antipsychotics frequently block D $3,{ }^{32,33}$ and a genetic variant of this receptor has been associated with risk of developing tardive dyskinesia, ${ }^{34}$ cariprazine is a partial agonist, so that some stimulation of the receptor continues even at maximal receptor occupancy. As would be expected from the receptor profile, cariprazine has demonstrated efficacy in animal models that examine cognition, ${ }^{24,35}$ depression, ${ }^{25}$ and mania. ${ }^{36}$

\section{Cariprazine in schizophrenia}

Four acute studies performed in subjects with schizophrenia have either been published directly, ${ }^{37}$ or presented in meetings and published in review format. ${ }^{38,39}$ In an early Phase II study, 392 subjects with acute schizophrenic psychosis were randomized to receive $1.5-3 \mathrm{mg} /$ day or 3-6 mg/day of cariprazine or placebo, after a 7-day washout, and followed for 6 weeks. ${ }^{38,39}$ A large fraction (46\%) discontinued the study early for a variety of reasons. A larger fraction of patients receiving placebo (15\%) stopped the study for lack of efficacy than in either active arm ( $8 \%$ in the low-dose arm and $9 \%$ in the high-dose arm) ${ }^{38}$ The score of the Positive and Negative Syndrome Scale (PANSS) improved significantly in patients receiving $1.5-3 \mathrm{mg} /$ day of cariprazine compared to placebo; the higher dose arm did not statistically separate from placebo. ${ }^{38}$

A second Phase II study which has been published ${ }^{40}$ randomized 732 subjects with acute schizophrenic psychosis to one of five arms: cariprazine $1.5 \mathrm{mg} / \mathrm{day}, 3 \mathrm{mg} / \mathrm{day}$, 
$4.5 \mathrm{mg}$ /day, placebo, or risperidone $4 \mathrm{mg}$ /day for 6 weeks. All active arms improved significantly compared to placebo. There appeared to be a dose-related change in magnitude of PANSS change with a least squares mean difference (LSMD) of $-7.6,-8.8$, and -10.4 for $1.5,3$, and $4.5 \mathrm{mg}$ /day of cariprazine, respectively; risperidone change was -15.1 , but the study was not powered to examine differences in the active arms. ${ }^{40}$

A Phase III study randomized 617 patients to cariprazine $3 \mathrm{mg} /$ day or $6 \mathrm{mg} /$ day, aripiprazole $10 \mathrm{mg}$ /day, or placebo. All active arms improved significantly compared to placebo. The cariprazine $6 \mathrm{mg}$ /day arm and aripiprazole group separated from placebo at week 1; the low-dose cariprazine arm separated from placebo at week 3 (due to the long halflife and delay in reaching steady state). ${ }^{38}$

A second Phase III study randomized 446 people with acute schizophrenia to three arms: cariprazine 3-6 mg/day $(\mathrm{n}=151)$, cariprazine $6-9 \mathrm{mg} /$ day $(\mathrm{n}=1,480)$, and placebo $(n=147) .{ }^{37}$ Both active arms improved significantly relative to placebo, but again there appeared to be a numerical dose effect with LSMD of -6.8 for the low-dose arm and -9.9 for the high-dose arm. ${ }^{37}$

Across the three published schizophrenia studies, males outnumbered females by a ratio of approximately $3: 1 .^{37,38,40}$ There were no reported differences in efficacy or AEs between the sexes.

In summary, short-term studies performed with cariprazine in patients with acute exacerbation of schizophrenia revealed the drug to be effective in a wide range of doses, and revealed that the extent of improvement is similar to established second-generation antipsychotics. There may be evidence of dose-responsiveness in the antipsychotic effect. This may be a true pharmacodynamics effect, or may be related to a pharmacokinetic effect where lower doses require a longer time to reach levels achieved at higher doses, and steady-state levels are not achieved in the brief 6-week period.

The side-effect profile in both the short-term and longterm studies was similar for patients with bipolar illness and patients with schizophrenia. The safety profile of cariprazine is discussed in the following section.

\section{Efficacy in bipolar illness}

Three randomized controlled trials have been conducted in patients with mania. ${ }^{38,41}$ A Phase II study randomized 238 adults to either a flexible-dose cariprazine (3-12 $\mathrm{mg} /$ day) or placebo. ${ }^{41}$ The majority of patients $(66.1 \%)$ reached $12 \mathrm{mg} /$ day, and the average dose was $8.8 \mathrm{mg} /$ day. $^{41}$
The LSMD by week 3 was -6.12 points on the Young Mania Rating Scale (YMRS) (Figure 1). Approximately, half of the patients (48\%) achieved at least a $50 \%$ improvement, or became euthymic (42\%) compared to one-quarter of placebotreated patients $\left(25 \%\right.$ and $23 \%$, respectively). ${ }^{37,41}$ As with nearly all of the cariprazine studies, dropout rates were high, so that $61.9 \%(n=73)$ of the placebo group and $63.6 \%(n=75)$ of the cariprazine group completed the study. ${ }^{37,41}$

Two Phase III trials with manic patients have been presented. The first trial randomized 312 acutely manic adults to either a flexible-dose cariprazine or placebo. Over half of the patients responded (59\%) or achieved remission $(52 \%)$ on cariprazine compared to significantly smaller numbers on placebo ( $44 \%$ and $35 \%$, respectively). ${ }^{42}$ The LSMD in YMRS score was -4.3 for the cariprazinetreated patients. ${ }^{42}$

In the second Phase III trial, 497 manic patients with mania were randomized to cariprazine $3-6 \mathrm{mg} / \mathrm{day}$, 6-12 mg/day, or placebo. ${ }^{43}$ The YMRS LSMD was essentially the same for both dose ranges $(-6.1$ points for the lower dose and -5.9 points for the higher dose, both $P<0.001) .{ }^{43}$ Only $25 \%$ of patients in this study achieved remission.

Cariprazine was also investigated as a potential antidepressant in depressed patients with bipolar and unipolar disorders. In a Phase II study, 233 depressed subjects with bipolar disorder were randomized to a very-low-dose arm (0.25-0.75 mg/day), a low-dose arm (1.5-3.0 mg/day), and placebo. There was no statistically significant separation from placebo. ${ }^{44}$ In a subsequent study, 584 depressed patients with bipolar disorder were treated for 8 weeks with cariprazine $0.75 \mathrm{mg} /$ day, $1.5 \mathrm{mg} /$ day, $3.0 \mathrm{mg} /$ day, or placebo. ${ }^{45}$ The group receiving $1.5 \mathrm{mg}$ of cariprazine improved transiently at week 6 (four-point improvement on Montgomery-Åsberg Depression Rating Scale, $P=0.003) .{ }^{45}$ These findings mirror other

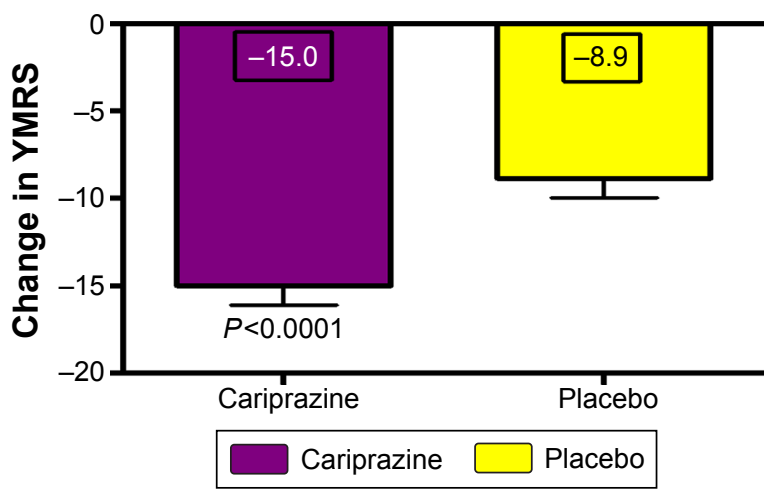

Figure I The reduction in the Young Mania Rating Scale (YMRS) for manic subjects being treated with cariprazine and placebo over 2I days (last observation carried forward).

Note: Data from Kane et al. ${ }^{37}$ 
observations with partial agonists. Brexpiprazole, which is a partial agonist antipsychotic drug recently approved as an adjunct for the treatment of unipolar depression, appeared to have a therapeutic window - in which $2 \mathrm{mg}$ /day was more effective than both $1 \mathrm{mg}$ and $3 \mathrm{mg}$ daily. ${ }^{46,47}$ Thus, the observation that $1.5 \mathrm{mg} /$ day of cariprazine is more effective than either a lower dose or a higher dose is not without precedent in this class of medications. Similarly, the phenomenon of a transient improvement was also observed with aripiprazole in bipolar depression $^{48}$ and may be a reflection of the combination of a therapeutic window and long drug half-life. Repeating the study with $1 \mathrm{mg} /$ day for a longer time period may clarify the actual efficacy of cariprazine in bipolar depression.

However, these conjectures are not supported by a Phase II study where the condition of 231 patients with treatmentresistant unipolar depression receiving $0.1-0.3 \mathrm{mg} /$ day or $1.0-2.0 \mathrm{mg} /$ day added to an antidepressant did not improve. ${ }^{49}$ Furthermore, the condition of 819 patients who received a higher dose of cariprazine added to an antidepressant for 8 weeks (2.0-4.5 mg/day + antidepressant) improved compared to placebo + antidepressant $(P=0.0114) .{ }^{50}$ Thus, cariprazine may indeed have efficacy in the treatment of depression (unipolar and/or bipolar), but the full nature of that effect is not clear.

\section{Safety and tolerability}

Cariprazine has been approved for use in patients with acute exacerbation of schizophrenia and bipolar mania (including mixed states). The AE profile in the short-term studies in schizophrenia and bipolar disorders is very similar. ${ }^{38-41,51-54}$

While the efficacy of cariprazine appears to be doserelated, so that doses of $3.0-4.5 \mathrm{mg}$ once daily are generally more effective than lower doses, tolerability does not appear to be dose-related. ${ }^{40}$ In most acute studies, more placebo-treated subjects compared to cariprazine discontinued treatment due to insufficient therapeutic response. ${ }^{40}$ Compared to other FDA-approved second-generation atypical antipsychotics, cariprazine is less likely to produce clinically significant metabolic side effects, such as weight gain, hyperlipidemia, hypercholesterolemia, and hyperglycemia, with any observed changes being similar to placebo. ${ }^{37,40,55}$ There are no significant ECG abnormalities ${ }^{55}$ and prolactin levels usually drop. ${ }^{55}$ Common AEs are either central (in order of decreasing frequency: insomnia, extrapyramidal symptoms, akathisia, sedation, dizziness, and anxiety) or gastrointestinal (nausea, constipation, and vomiting). ${ }^{7,40,41}$ In patients with bipolar illness, measuring akathisia (utilizing the Barnes
Akathisia Rating Scale) reveals a nonsignificant increase in akathisia with cariprazine versus placebo (0.4 vs 0.09 , $P=0.12) .{ }^{41}$ However, when parkinsonism is measured by the Simpson Angus Scale, there is a significantly greater level of extrapyramidal symptoms in patients receiving cariprazine (1.17) versus placebo $(0.09, P<0.01) .{ }^{41}$ In most studies, AEs did not appear to be dose related. ${ }^{41,55}$ However, in one unpublished acute mania study, AEs occurred at greater frequency at higher doses (6-12 mg/day) compared to lower doses (3-6 mg/day), and both greater than placebo. ${ }^{7}$

There were no reported abnormalities in liver function or P450 enzyme function with cariprazine treatment. However, due to the long half-life of the drug and its equipotent active metabolites, the FDA added a warning that cariprazine may have late-occurring AEs, occurring after weeks of treatment.

In summation, cariprazine was considered safe and well tolerated among adult patients diagnosed with acute schizophrenia and bipolar mania.

\section{Conclusion}

Partial agonists of the dopamine system are becoming the preferred class of medications over pure antagonists in treatment of both psychosis and mood disturbance. This is because tolerance to the medication is less likely to occur when the receptor is both blocked and stimulated at the same time. Cariprazine is a partial agonist at D2, D3, and $5 \mathrm{HT}_{1 \mathrm{~A}}$ receptors. The affinity at the D3 receptor is approximately six times greater than at the D2 receptor. However, it is administered at a dose that generally blocks the majority of both of these receptors.

Studies with partial agonists, particularly with long halflives are frequently difficult to predict, and this appears to be the case with cariprazine. In studies with patients with bipolar mania or schizophrenic psychosis, cariprazine has shown significant efficacy and a tolerable AE profile. However, it is much more difficult to interpret the depression data. The data are consistent with the interpretation of a window in which the drug may be effective with depression, in a manner similar to aripiprazole and brexpiprazole. The task of understanding the effect of the drug is made more difficult by the paucity of publications of the completed clinical trials. Nonetheless, the recent approval of cariprazine provides a new tool for clinicians, which appears to have unique mechanistic profile.

\section{Disclosure}

Dr Rif S El-Mallakh has grant funding from the National Institute of Mental Health, the State of Kentucky, Merck, 
Teva, and Psychnostics; and is a speaker for Allergan, Lundbeck, Merck, Otsuka, Sunovion, and Takeda. He reports no other conflicts of interest in this work. The other authors report no conflicts of interest in this work.

\section{References}

1. Dunlop J, Brandon NJ. Schizophrenia drug discovery and development in an evolving era: are new drug targets fulfilling expectations? J Psychopharmacol. 2015;29(2):230-238.

2. Mailman RB, Murthy V. Third generation antipsychotic drugs: partial agonism or receptor functional selectivity? Curr Pharm Des. 2010;16(5): 488-501.

3. Jann MW. Diagnosis and treatment of bipolar disorders in adults: a review of the evidence on pharmacologic treatments. Am Health Drug Benefits. 2014;7(9):489-499.

4. Roberts RJ, Lohano KK, El-Mallakh RS. Antipsychotics as antidepressants. Asia Pac Psychiatry. Epub 2015 May 12.

5. Nierenberg AA, McIntyre RS, Sachs GS. Improving outcomes in patients with bipolar depression: a comprehensive review. J Clin Psychiatry. 2015;76(3):e10.

6. Ágai-Csongor É, Domány G, Nógrádi K, et al. Discovery of cariprazine (RGH-188): a novel antipsychotic acting on dopamine $\mathrm{D}_{3} / \mathrm{D}_{2}$ receptors Bioorg Med Chem Lett. 2012;22:3437-3440.

7. Citrome L. Cariprazine: chemistry, pharmacodynamics, pharmacokinetics, and metabolism, clinical efficacy, safety, and tolerability. Expert Opin Drug Metab Toxicol. 2013;9(2):193-206.

8. Kiss B, Horváth A, Némethy Z, et al. Cariprazine (RGH-188), a dopamine $\mathrm{D}_{3}$ receptor-preferring, $\mathrm{D}_{3} / \mathrm{D}_{2}$ dopamine receptor antagonistpartial agonist antipsychotic candidate: in vitro and neurochemical profile. J Pharmacol Exp Therap. 2010;333(1):328-340.

9. Seneca N, Finnema SJ, Laszlovszky I, et al. Occupancy of dopamine $\mathrm{D}_{2}$ and $\mathrm{D}_{3}$ and serotonin $5-\mathrm{HT}_{1 \mathrm{~A}}$ receptors by the novel antipsychotic drug candidate, cariprazine (RGH-188), in monkey brain measured using positron emission tomography. Psychopharmacology (Berl). 2011; 218(3):579-587.

10. Potkin S, Keator D, Mukherjee J, et al. (P.1.e.028) Dopamine D3 and D2 receptor occupancy of cariprazine in schizophrenic patients Eur Neuropsychopharmacol. 2009;19(Suppl 3):S316.

11. Laszlovsky I, Németh G, Mészáros P, et al. (P.3.c.053) Dopamine D2/ D3 receptor occupancy of RGH-188, a D3/D2 antagonist/partial agonist antipsychotic, in healthy volunteers. Eur Neuropsychopharmacol.2007; 17(Suppl 4):S455.

12. Mészáros GP, Kapás M, Borsos M, et al. (P.3.c.047) Pharmacokinetics of RGH-188, a new dopamine D3/D2 antagonist/partial agonist atypical antipsychotic, in healthy subjects. Eur Neuropsychopharmacol. 2007;17(Supp1 4):S451-S452.

13. Kapás M, Mészáros GP, Yu B, et al. (P.3.c.051) Comparison of the pharmacokinetic behaviour of RGH-188 in schizophrenic patients and healthy volunteers. Eur Neuropsychopharmacol. 2008; 18(Suppl 4):S433.

14. Pásztor Mészáros G, Agai-Csongor E, Kapaś M. Sensitive LC-MS/MS methods for the quantification of RGH-188 and its active metabolites, desmethyl- and didesmethyl-cariprazine in human plasma and urine. J Pharm Biomed Anal. 2008;48(2):388-397.

15. Kirschner N, Gémesi LI, Vastag M, et al. In vitro metabolism of RGH-188. Presented at the 10th European International Society of the Study of Xenobiotics (ISSX), Meeting; May 18-21; 2008. Available from: https://issx.confex.com/issx/10euro/webprogram/ Paper8686.html. Accessed September 30, 2015.

16. Kapur S, Remington G, Jones C, et al. High levels of dopamine D-2 receptor occupancy with low-dose haloperidol treatment: a PET study. Am J Psychiatry. 1996;153(7):948-950.

17. Johnson M, Kozielska M, Pilla Reddy V, et al. Dopamine D2 receptor occupancy as a predictor of catalepsy in rats: a pharmacokinetic-pharmacodynamic modeling approach. Pharm Res. 2014;31(10):2605-2617.
18. Nordström AL, Farde L, Wiesel FA, et al. Central D2-dopamine receptor occupancy in relation to antipsychotic drug effects - a double-blind PET study of schizophrenic-patients. Biol Psychiatry. 1993;33(4): $227-235$.

19. Horacek J, Bubenikova-Valesova V, Kopecek M, et al. Mechanism of action of atypical antipsychotic drugs and the neurobiology of schizophrenia. CNS Drugs. 2006;20(5):389-409.

20. Madras BK. History of the discovery of the antipsychotic dopamine D2 receptor: a basis for the dopamine hypothesis of schizophrenia. J Hist Neurosci. 2013;22(1):62-78.

21. Seeman P. Atypical antipsychotics: mechanism of action. Can J Psychiatry. 2002;47:27-38.

22. Kapur S, Zipursky R, Roy P, et al. The relationship between D2 receptor occupancy and plasma levels on low dose oral haloperidol: a PET study. Psychopharmacology (Berl). 1997;131(2):148-152.

23. Sheynikhovich D, Otani S, Arleo A. The role of tonic and phasic dopamine for long-term synaptic plasticity in the prefrontal cortex: a computational model. J Physiol Paris. 2011;105(1-3):45-52.

24. Zimnisky R, Chang G, Gyertyán I, et al. Cariprazine, a dopamine $\mathrm{D}_{3}$-receptor-preferring partial agonist, blocks phencyclidine-induced impairments of working memory, attention set-shifting, and recognition memory in the mouse. Psychopharmacology (Berl). 2013;226(1): 91-100.

25. Papp M, Gruca P, Lasoń-Tyburkiewicz M, Adham N, Kiss B, Gyertyán I Attenuation of anhedonia by cariprazine in the chronic mild stress model of depression. Behav Pharmacol. 2014;25(5-6):567-574.

26. Newman-Tacredi A. The importance of $5 \mathrm{HT}_{1 \mathrm{~A}}$ receptor agonism in antipsychotic drug action: rationale and perspectives. Curr Opin Investig Drugs. 2010;11(7):802-812.

27. Bouthenet ML, Souil E, Martres MP, Sokoloff P, Giros B, Schwartz JC. Localization of dopamine $\mathrm{D}_{3}$ receptor mRNA in the rat brain using in situ hybridization histochemistry: comparison with dopamine $\mathrm{D}_{2}$ receptor mRNA. Brain Res. 1991;564:203-221.

28. Diaz J, Lévesque D, Griffon N, et al. Opposing roles for dopamine $\mathrm{D}_{2}$ and $\mathrm{D}_{3}$ receptors on neurotensin mRNA expression in nucleus accumbens. Eur J Neurosci. 1994;6:1384-1387.

29. Ridray S, Griffon N, Mignon V, et al. Coexpression of dopamine $D_{1}$ and $\mathrm{D}_{3}$ receptors in islands of Calleja and shell of nucleus accumbens of the rat: opposite and synergistic functional interactions. Eur J Neurosci. 1998;10:1676-1686.

30. SimpsonEH, Winiger V, Biezonski DK, Haq I, Kandel ER, Kellendonk C. Selective overexpression of dopamine D3 receptors in the striatum disrupts motivation but not cognition. Biol Psychiatry. 2013;76(10): 823-831.

31. Barth V, Need AB, Tzavara ET, et al. In vivo occupancy of dopamine D3 receptors by antagonists produces neurochemical and behavioral effects of potential relevance to attention-deficit-hyperactivity disorder. J Pharmacol Exp Ther. 2013;344(2):501-510.

32. Sokoloff P, Giros B, Martres MP, Bouthenet ML, Schwartz J. Molecular cloning and characterization of a novel dopamine receptor $\left(\mathrm{D}_{3}\right)$ as a target for neuroleptics. Nature. 1990;347:146-151.

33. Sokoloff P, Diaz J, Levesque D, et al. Novel dopamine receptor subtypes as targets for antipsychotic drugs. Ann NY Acad Sci. 1995;757: 278-292.

34. Bakker PR, van Harten PN, van Os J. Antipsychotic-induced tardive dyskinesia and the Ser9Gly polymorphism in the DRD3 gene: a meta analysis. Schizophr Res. 2006;83(2-3):185-192.

35. Gyertyán I, Kiss B, Sághy K, et al. Cariprazine (RGH-188), a potent D3/D2 dopamine receptor partial agonist, binds to dopamine D3 receptors in vivo and shows antipsychotic-like and procognitive effects in rodents. Neurochem Int. 2011;59(6):925-935.

36. Gao Y, Peterson S, Masri B, et al. Cariprazine exerts antimanic properties and interferes with dopamine $\mathrm{D}_{2}$ receptor $\beta$-arrestin interactions. Pharmacol Res Perspect. 2015;3(1):e00073.

37. Kane JM,Zukin S, Wang Y, et al. Efficacy and safety of cariprazine in acute exacerbation of schizophrenia: results from an International, phase III clinical trial. J Clin Psychopharmacol. 2015;35(4):367-373. 
38. Citrome L. Cariprazine in schizophrenia: clinical efficacy, tolerability, and place in therapy. Adv Ther. 2013;30(2):114-126.

39. Forest Laboratories, Inc. Forest Laboratories, Inc. and Gedeon Richter Plc. announce results from two phase III trials with the investigational antipsychotic cariprazine for the treatment of schizophrenia [press release]. Forest Laboratories, Inc.; 2012 [November 6]. Available from: http://news.frx.com/press-release/rd-news/forest-laboratoriesinc-and-gedeon-richter-plc-announce-results-two-positive-p. Accessed September 29, 2014.

40. Durgam S, Starace A, Li D, et al. The efficacy and tolerability of cariprazine in acute mania associated with bipolar I disorder: a phase II trial. Bipolar Disord. 2015;17(1):63-75.

41. Durgam S, Starace A, Li D, et al. An evaluation of the safety and efficacy of cariprazine in patients with acute exacerbation of schizophrenia: a phase II, randomized clinical trial. Schiz Res. 2014;152:450-457.

42. Sachs GS, Greenberg WM, Starace A, et al. Cariprazine in the treatment of acute mania in bipolar I disorder: a double-blind, placebo-controlled, Phase III trial. $J$ Affect Disord. 2015;174:296-302.

43. Calabrese JR, Keck PE Jr, Starace A, et al. Efficacy and safety of lowand high-dose cariprazine in acute and mixed mania associated with bipolar I disorder: a double-blind, placebo-controlled study. J Clin Psychiatry. 2015;76(3):284-292.

44. Forest Laboratories, Inc. Forest Laboratories, Inc. and Gedeon Richter Plc announce results from a Phase II study of cariprazine for the treatment of bipolar depression [press release]; 2010 [August 30]. Available from: http://news.frx.com/press-release/rd-news/forest-laboratoriesinc-and-gedeon-richter-plc-announce-results-phase-ii-stu-0. Accessed January 17, 2016

45. Forest Laboratories, Inc. Forest Laboratories, Inc. and Gedeon Richter Plc. Announce positive Phase IIb topline results for cariprazine for the treatment of bipolar depression [press release]; 2014 [March 31]. Available from: http://investor.frx.com/press-release/r-and-d-news/ forest-laboratories-inc-and-gedeon-richter-plc-announce-positivephase-0. Accessed January 17, 2016.

46. Thase ME, Youakim JM, Skuban A, et al. Adjunctive brexpiprazole 1 and $3 \mathrm{mg}$ for patients with major depressive disorder following inadequate response to antidepressants: a phase 3, randomized, double-blind study. J Clin Psychiatry. 2015;76(9):1232-1240.
47. Thase ME, Youakim JM, Skuban A, et al. Efficacy and safety of adjunctive brexpiprazole $2 \mathrm{mg}$ in major depressive disorder: a phase 3, randomized, placebo-controlled study in patients with inadequate response to antidepressants. J Clin Psychiatry. 2015;76(9):1224-1231.

48. Thase ME, Jonas A, Khan A, et al. Aripiprazole monotherapy in nonpsychotic bipolar I depression: results of 2 randomized, placebo-controlled studies. J Clin Psychopharmacol. 2008;28(1):13-20.

49. Forest Laboratories, Inc. Forest Laboratories, Inc. and Gedeon Richter Plc announce results from a Phase II study of cariprazine as adjunctive therapy in major depressive disorder [press release]; 2011 [February 28]. Available from: http://investor.frx.com/press-release/rd-news/forestlaboratories-inc-and-gedeon-richter-plc-announce-results-phase-iistudy. Accessed January 17, 2016.

50. Forest Laboratories, Inc. Forest Laboratories, Inc. and Gedeon Richter Plc. announce positive Phase IIb topline results for cariprazine as adjunctive therapy in the treatment of major depressive disorder [press release]; 2014 [March 21]. Available from: http://investor.frx.com/ press-release/r-and-d-news/forest-laboratories-inc-and-gedeon-richterplc-announce-positive-phase-ii. Accessed 17 January, 2016.

51. El-Mallakh RS, Elmaadawi AZ, Gao Y, Lohano K, Roberts RJ. Current and emerging therapies for the management of bipolar disorders. J Cent Nerv System Disord. 2011;3:189-197.

52. George M, Amrutheshwar R, Rajkumar RP, Kattimani S, Dkhar SA. Newer antipsychotics and upcoming molecules for schizophrenia. Eur J Clin Pharmacol. 2013;69:1498-1509.

53. Lieberman J, Cutler A, Wan S, et al. Cariprazine in acute exacerbation of schizophrenia: a fixed-dose randomised, double-blind, placeboand-active-controlled trial. Eur Neuropsychopharmacol. 2013;23: S477-S478.

54. Zukin SR, Kane J, Cutler AJ, et al. Efficacy and safety of cariprazine in acute exacerbation of schizophrenia: a phase III, international, randomized, double-blind, placebo-controlled trial. Neuropsychopharmacology. 2012;38(Suppl 1):S319.

55. Citrome L. Cariprazine in schizophrenia: clinical efficacy, tolerability, and place in therapy. Adv Therap. 2013;30(2):114-126.
Neuropsychiatric Disease and Treatment

\section{Publish your work in this journal}

Neuropsychiatric Disease and Treatment is an international, peerreviewed journal of clinical therapeutics and pharmacology focusing on concise rapid reporting of clinical or pre-clinical studies on a range of neuropsychiatric and neurological disorders. This journal is indexed on PubMed Central, the 'PsycINFO' database and CAS,

\section{Dovepress}

and is the official journal of The International Neuropsychiatric Association (INA). The manuscript management system is completely online and includes a very quick and fair peer-review system, which is all easy to use. Visit http://www.dovepress.com/testimonials.php to read real quotes from published authors. 